\title{
Mouse model for the lysosomal disorder galactosialidosis and correction of the phenotype with overexpressing erythroid precursor cells
}

\author{
Xiao Yan Zhou, ${ }^{1}$ Hans Morreau, ${ }^{1,2}$ Robbert Rottier, ${ }^{1}$ Donna Davis, ${ }^{3}$ Erik Bonten, ${ }^{1}$ \\ Nynke Gillemans, ${ }^{4}$ David Wenger, ${ }^{5}$ Frank G. Grosveld, ${ }^{4}$ Peter Doherty, ${ }^{6}$ Kinuko Suzuki, \\ Gerard C. Grosveld, ${ }^{1}$ and Alessandra d'Azzo ${ }^{1,8}$ \\ Departments of ${ }^{1}$ Genetics, ${ }^{3}$ Virology and Molecular Biology, and ${ }^{6}$ Immunology, St. Jude Children's Research Hospital, \\ Memphis, Tennessee 38105 USA; Departments of ${ }^{2}$ Pathology and ${ }^{4}$ Cell Biology, Erasmus University, Medical Faculty 3000 \\ DR Rotterdam, The Netherlands; ${ }^{5}$ Division of Medical Genetics, Jefferson Medical College, Philadelphia, Pennsylvania \\ 19107-5563 USA; ${ }^{7}$ Department of Pathology, University of North Carolina, Chapel Hill, North Carolina 27514 USA
}

The lysosomal storage disorder galactosialidosis results from a primary deficiency of the protective protein/cathepsin A (PPCA), which in turn affects the activities of $\beta$-galactosidase and neuraminidase. Mice homozygous for a null mutation at the PPCA locus present with signs of the disease shortly after birth and develop a phenotype closely resembling human patients with galactosialidosis. Most of their tissues show characteristic vacuolation of specific cells, attributable to lysosomal storage. Excessive excretion of sialyloligosaccharides in urine is diagnostic of the disease. Affected mice progressively deteriorate as a consequence of severe organ dysfunction, especially of the kidney. The deficient phenotype can be corrected by transplanting null mutants with bone marrow from a transgenic line overexpressing human PPCA in erythroid precursor cells. The transgenic bone marrow gives a more efficient and complete correction of the visceral organs than normal bone marrow. Our data demonstrate the usefulness of this animal model, very similar to the human disease, for experimenting therapeutic strategies aimed to deliver the functional protein or gene to affected organs. Furthermore, they suggest the feasibility of gene therapy for galactosialidosis and other disorders, using bone marrow cells engineered to overexpress and secrete the correcting lysosomal protein.

[Key Words: Mouse model; galactosialidosis; lysosomal disease; protective protein; erythroid expression; BMT] Received August 4, 1995; revised version accepted September 7, 1995.

Galactosialidosis (for review, see d'Azzo et al. 1995) is a lysosomal storage disease, inherited as an autosomal recessive trait and characterized by a combined deficiency of $\beta$-D-galactosidase and $N$-acetyl- $\alpha$-neuraminidase, secondary to a defect of the protective protein/cathepsin A (PPCA) (Wenger et al. 1978; d'Azzo et al. 1982). This serine carboxypeptidase (Galjart et al. 1988; Rawlings and Barrett 1994) has at least two distinct functions. First, as demonstrated by copurification experiments (Verheijen et al. 1982; Yamamoto and Nishimura 1987; Potier et al. 1990; Scheibe et al. 1990; Hubbes et al. 19921, it associates with the two glycosidases, thereby modulating their intralysosomal stability and activity (Hoogeveen et al. 1983; van der Horst et al. 1989; Galjart et al. 1991). Second, the protein is catalytically active as a lysosomal cathepsin at acidic $\mathrm{pH}$, as well as a deami-

${ }^{8}$ Corresponding author. dase/esterase at neutral $\mathrm{pH}$, and has been shown to participate in the inactivation of selected neuropeptides like substance $P$, oxytocin, and endothelin I (Jackman et al. 1990; Galjart et al. 1991; Jackman et al. 1992; Hanna et al. 1994). Mammalian and avian protective proteins are highly conserved and share homology to yeast and plant serine carboxypeptidases (Galjart et al. 1988; Galjart et al. 1991). The murine and avian enzymes can even substitute for their human homolog to stabilize and activate human $\beta$-galactosidase and neuraminidase (Galjart et al. 1991).

Patients with galactosialidosis have clinical manifestations indicative of a lysosomal disorder, including coarse facies, ocular cherry red spots, vertebral changes, foamy cells in the bone marrow, and vacuolated lymphocytes in peripheral blood. Based on the age of onset of the symptoms, three clinical phenotypes are distinguished: early infantile, late infantile, and juvenile/adult variants. The most severe early infantile form is associated 
with fetal hydrops, diffuse edema, ascites, hepatosplenomegaly, psychomotor delay, bone deformity, and severe heart and kidney involvement. Death occurs within the first year of age, likely as a result of renal failure. Late infantile and juvenile/adult patients have a later onset and slower progression of the disease; however, whereas adult patients have central nervous system (CNS) involvement, the late infantile types are not mentally retarded or only mildly so. In spite of the triple enzyme deficiency, the storage products isolated from tissues and urine of galactosialidosis patients are primarily sialylated oligosaccharides (Okada et al. 1978; van Pelt et al. 1988a,b, 1989). The characteristic pathology of the disease includes vacuolation of cells in the central, peripheral, and autonomic nervous systems, retina, liver, kidney, skin, and peripheral blood (d'Azzo et al. 1995).

There is currently no effective therapy for galactosialidosis or for other lysosomal disorders with CNS involvement. Transplantation of allogeneic bone marrow as a source of normal enzyme has proven of limited benefit in human studies with other lysosomal diseases (for review, see Krivit et al. 1992; Hoogerbrugge et al. 1995), but has never been tried for galactosialidosis. Also in naturally occurring animal models with these disorders, the effect of bone marrow transplantation (BMT) has been variable (for review, see Haskins et al. 1991). Improvement of the pathology was observed after BMT in cats with $\alpha$-mannosidosis (Walkley et al. 1994a), but only partial correction was obtained with this procedure in mice with mucopolysaccharidosis VII (Birkenmeier et al. 1991) and no amelioration was detected in treated $\mathrm{G}_{\mathrm{M} 2}$-gangliosidosis cats (Walkley et al. 1994b). This difference may depend on the number of perivascular monocytes/macrophages originating from the graft but also on differential secretion of the correcting enzyme by donor-derived cells, as seems to be the case for $\alpha$-mannosidase and $\beta$-hexosaminidase, at least in in vitro studies (Dobrenis et al. 1994). Other novel approaches, like intraperitoneal implant of fibroblasts organoids (Moullier et al. 1995) or direct transfer of neuronal progenitor cells (Snyder et al. 1995), have been employed recently for the local delivery of exogenous functional enzyme to the liver and the CNS, respectively. Overall, these studies establish the validity of suitable animal models, which closely resemble the human disease, to evaluate therapeutic strategies for the correction of disorders like galactosialidosis. Although sheep with a combined $\beta$-galactosidase and neuraminidase deficiency have been identified (Ahern-Rindell et al. 1988), both the localization of severe storage only to neurons and the enzymatic characteristics differentiate this model from the human disease. Recently, a disease with pathology similar to the adult form of galactosialidosis was described in a Schipperke dog (Knowles et al. 1993), but the biochemical data were insufficient to verify the diagnosis. To produce an animal model for galactosialidosis we have generated mice carrying a null mutation at the PPCA locus. Deficient animals are viable and fertile but exhibit severe abnormalities soon after birth that closely resemble those found in galactosialidosis patients. They also de- velop the characteristic histopathology of the human disease. Thus, this mouse model provides an attractive opportunity to study the pathogenesis and pathophysiology of the disease and to evaluate experimental therapies, including gene therapy. In this report we have tested the hypothesis that substantial secretion of PPCA by genetically modified bone marrow cells could translate into a more timely and effective correction of the lesions in affected mice. We demonstrate that treatment of the $|-|-\mid$ phenotype with transgenic bone marrow overexpressing the human PPCA in erythroid precursors, which also secrete the protein at high levels, can improve the pathological conditions better than normal bone marrow cells. These results give the first indication of the potential of overproducing and secreting hematopoietic cells for the treatment of galactosialidosis and possibly other similar disorders.

\section{Results}

\section{Generation of PPCA-deficient mice}

A targeting vector for homologous recombination at the murine PPCA locus was constructed as outlined in Figure 1A. The position of the positive selectable marker prevents translation of the polypeptide and thus the targeted replacement constitutes a genuine null mutation. Targeted E14 embryonic stem (ES) cells were obtained at a frequency of $13 \%-15 \%$. Chimeric males derived from two independent clones (28 and 139) yielded germ-line transmission of the null allele. Interbreeding of heterozygotes $1+1-\mid$ from both clones readily generated homozygous $(-/-\mid$ mice. Offspring were genotyped by Southern blotting and hybridization with a $5^{\prime}$ external probe (Fig. 1B). Combined data from crosses between clone 28 and/ or clone 139 heterozygotes showed a distribution of $24 \%$ $(+1+), 20 \%(-1-)$, and $56 \%(+/-)$ in 292 offspring analyzed, suggesting that an intact PPCA gene is not required for normal embryonic development of homozygous null mice. Northern blot analysis (Fig. 1C) of total RNA isolated from PPCA $(-/-)$ tissues confirmed the lack of a PPCA transcript in deficient mice.

\section{Biochemical analysis of PPCA-deficient mice}

The engineered mutation rendered $(-1-)$ mice unable to encode the PPCA protein, as established by assaying cathepsin A activity in cultured fibroblasts and tissues from $(+1+1,1+1-1$, and $(-1-1$ mutant animals of different age (Table 1). This catalytic activity either was absent or reduced severely in tissues of homozygous mutant mice, with the levels ranging from nondetectable in bone marrow to $\sim 8 \%$ of normal in liver. The small, residual activity measured in some of the samples may be attributable to the presence of catalytically related proteins that have a low affinity for the Z-Phe-Ala substrate. Heterozygous mice showed clear intermediate values (Table 1). Because direct biochemical evidence of galactosialidosis in human patients is the combined deficiency of neuraminidase and $\beta$-galactosidase in fibro- 
A

Targeting vector

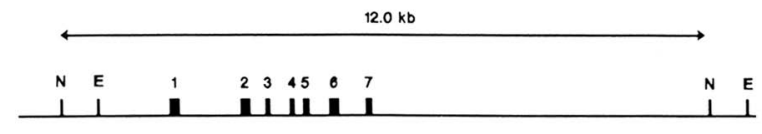

Wild type PP locus

Mutant PP locus

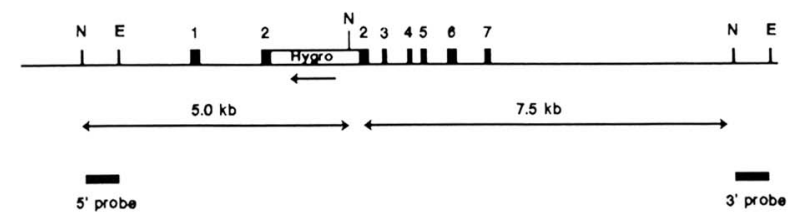

B

Nde I

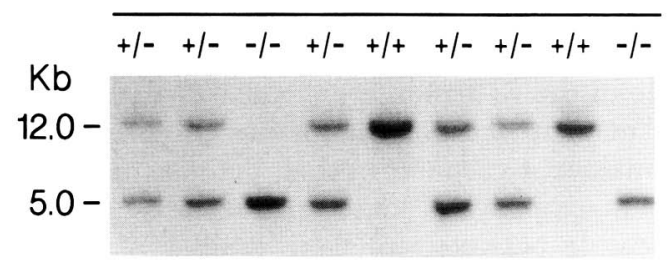

C

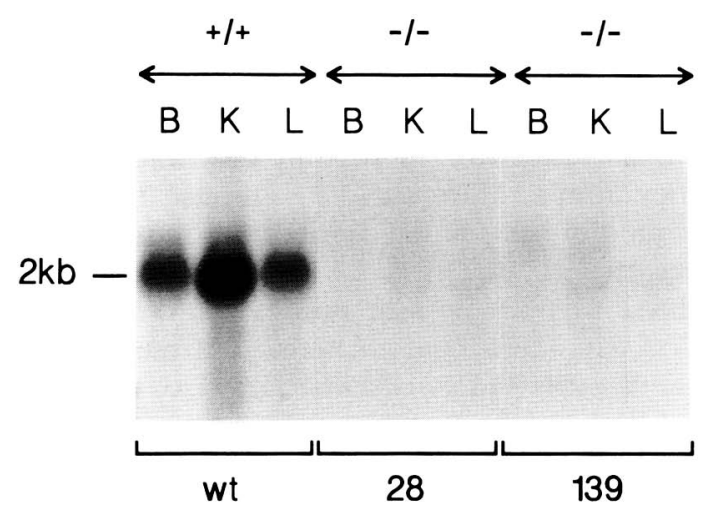

blasts and leukocytes (d'Azzo et al. 1995), we assessed these parameters in the mutant mice. The deficiency of cathepsin $\mathrm{A}$ in $(-1-)$ tissues directly influenced the activity of neuraminidase, which was severely reduced, especially in fibroblasts and kidney samples (Table 1). However, $\beta$-galactosidase levels varied considerably for the different tissues from deficient mice, being $\sim 20 \%$ of normal levels in fibroblasts, as found in human galactosialidosis $(10 \%-15 \%)$, but even higher than normal in liver. These results suggest that murine $\beta$-galactosidase may be less dependent for its stability and activity on complex formation with PPCA than is murine neuraminidase.

A second parameter used in clinical diagnosis is the overexcretion of undegraded sialyloligosaccharides in the urine of affected individuals (van Pelt et al. 1989). The total content of these metabolites in PPCA $(-1-)$ mice thus was determined for urine from PPCA $(-1-1$,
Figure 1. Targeted disruption of the PPCA locus by homologous recombination. $(A)$ Structure of a portion of the $P P C A$ gene, the targeting construct, and the predicted structure of the targeted PPCA locus following homologous recombination. Only the relevant restriction sites are shown: (E) EcoRI; $(\mathrm{N})$ NdeI. The numbered solid boxes represent exons. The labeled boxes indicate the position of the respective $5^{\prime}$ and $3^{\prime}$ hy probes. Horizontal single arrows indicate the direction of transcription of the hygro and TK cassettes. Two-headed arrows show the position and size of NdeI restriction fragments diagnostic for proper targeting of the locus. $(B)$ Southern blot analysis of $N d e I-$ digested genomic DNA of nine mice from one litter resulting from a cross between two PPCA $(+1-)$ mice. The blot was hybridized with the $5^{\prime}$ NdeI-EcoRI probe. The wild-type and mutant alleles are indicated by $12-$ and $5-\mathrm{kb}$ NdeI fragments, respectively. $(C)$. Northern blot analysis of PPCA mRNA from mouse tissues. Total RNAs: $(20 \mu \mathrm{g})$ from brain $(\mathrm{B})$, kidney $(\mathrm{K})$, and liver $\{\mathrm{L}\}$ of a wild-type $(+1+)$ mouse and two mutant $\{-1$ $-\mid$ mice derived from ES clone 28 and 139 were analyzed by Northern blotting with the PPCA mouse cDNA probe. The expected $2-\mathrm{kb}$ mRNA, detected in normal tissues, is absent in tissues from the mutant mice.

$(+1-1$, and $(+1+1$ mice. Twenty-one affected mice, tested between the age of 2 and 5 months excreted 3-10 times more sialylated oligosaccharides in urine than their normal and heterozygous littermates (Table 2). The amount of accumulated products increased progressively with time, eventually reaching levels 25 times higher than controls and heterozygotes in seven $|-|-\mid$ mice tested at the age of 6-8 months. These biochemical data clearly mirror the situation for humans with galactosialidosis and establish the validity of this model as an experimental substrate.

\section{Phenotypic characterization and histopathology of deficient mice}

PPCA $(-/-)$ mice are viable and fertile, and die at $\sim 12$ months of age. At birth and during the first 6 weeks of life their gross appearance was normal, except for an ap- 
Table 1. Lysosomal enzyme activities in cultured fibroblasts and tissues from PPCA $(-/-)$ mice

\begin{tabular}{|c|c|c|c|c|c|c|c|}
\hline & \multicolumn{3}{|c|}{$\begin{array}{c}\text { Cathepsin A } \\
\text { (mmole/min/mg }\end{array}$} & \multicolumn{2}{|c|}{$\begin{array}{r}\text { Neuraminidase } \\
\text { (nmole/hr/mg) }\end{array}$} & \multicolumn{2}{|c|}{$\begin{array}{l}\beta \text {-galactosidase } \\
\text { (nmole/hr/mg) }\end{array}$} \\
\hline & $+1+$ & $+1-$ & $-1-$ & $+1+$ & $-1-$ & $+/+$ & $-1-$ \\
\hline Fibroblast & $159 \pm 9$ & $98 \pm 17$ & $1.3 \pm 0.9$ & $23.00 \pm 0.10$ & $0.43 \pm 0.17$ & $812 \pm 82$ & $263 \pm 50$ \\
\hline Kidney & $135 \pm 14$ & $61 \pm 8$ & $1.8 \pm 0.9$ & $40.00 \pm 6.40$ & $0.57 \pm 0.09$ & $275 \pm 72$ & $176 \pm 25$ \\
\hline Brain & $20 \pm 3$ & $10 \pm 2$ & $0.7 \pm 0.3$ & $3.06 \pm 0.36$ & $0.98 \pm 0.19$ & $68 \pm 21$ & $59 \pm 9$ \\
\hline Spleen & $114 \pm 16$ & $43 \pm 18$ & $5.5 \pm 2.3$ & $4.00 \pm 1.92$ & $0.94 \pm 0.21$ & $291 \pm 51$ & $240 \pm 46$ \\
\hline Liver & $77 \pm 19$ & $31 \pm 13$ & $3.8 \pm 1.1$ & $3.78 \pm 0.66$ & $0.42 \pm 0.07$ & $68 \pm 8$ & $144 \pm 22$ \\
\hline Bone marrow & $163 \pm 27$ & N.D. & $0.0 \pm 0.0$ & $3.66 \pm 0.36$ & $0.19 \pm 0.02$ & $119 \pm 11$ & $106 \pm 25$ \\
\hline
\end{tabular}

Fibroblast cell lysates and total tissue homogenates in $\mathrm{H}_{2} \mathrm{O}$ from PP normal $|+|+\mid$, heterozygous $|+|-\mid$, and homozygous $|-/-|$ mice were assayed for cathepsin A activity, using the acylated dipeptide Z-Phe-Ala, and for neuraminidase and $\beta$-galactosidase activities, using synthetic 4-methylumbelliferyl substrates. Values represent means \pm S.E.M. of measurements done on $4(+1+1,2 \mid+/-1$, and 7 $(-1-)$ mice. All mice were between 2 and 8 weeks of age and were derived from ES cell clones 28 and 139. (N.D.) Not done.

parent flattening of the face. However, the majority of young $(-/-)$ mice weighed $25 \%-40 \%$ less than $(+/+)$ and $(+1-)$ littermates and were identified readily by size. Two of the smallest mice died spontaneously at 3 weeks of age and were found to have hepatic and splenic enlargement. No distinguishable skeletal deformities were observed in the young $|-|-\mid$ mice, but their physical condition overall worsened with age. Progressive and diffuse edema was accompanied by apparent ataxic movements and tremor. The characteristic broad face, rough coat, and extensive swelling of subcutaneous tissues, limbs, and eyelids are obvious in the 10-month-old $|-|-\mid$ mouse shown in Figure 2.

Visceromegaly is a specific clinical abnormality associated with the early and sometimes late infantile forms with galactosialidosis. This feature was also found in PPCA $(-1-1$ mice with enlargement of both the liver and the spleen being prominent at autopsy (not shown). Morphological studies of tissues from $(-/-)$ mice were carried out on either paraffin, cryosections, or epoxyresin sections examined both by light and electron microscopy. Affected mice were sacrificed at the age of 14 days, 1 month, 3-4 months, 6 months, and 10 months.
Signs of metabolic storage were found primarily in the reticuloendothelial system of most organs, already noticeable in the first mouse analyzed 14 days after birth. Thirty percent of the lymphocytes in peripheral blood had translucent vacuoles in their cytoplasm. In the skin, foamy macrophages, sometimes clearly perivascular, were visible between collagen bundles of the dermis. The presence of stored material was confirmed by positive cytoplasmic staining with periodic acid-Schiff (PAS) and diastase treatment (PAS +1 . The kidney appeared to be the earliest and most severely affected organ in young mutant mice, analogous to the situation for severe human disease. Electron microscopy of ultrathin sections of kidney from a 14-day-old $(-/-)$ mouse demonstrated vacuolation of the tubular epithelium, most evident in the proximal tubules (Fig. 3A), whereas distal tubules and glomeruli were less or minimally affected at this stage (Fig. 3B). The numerous membrane-bound vacuoles representing secondary lysosomes appeared either empty or filled with sparse fibrillar structures, reflecting lysosomal accumulation of low molecular weight compounds (e.g., oligosaccharides or glycopeptides).

This spectrum of pathological changes worsened pro-

Table 2. Total urinary sialyloligosaccharides in affected and BM-transplanted mice

\begin{tabular}{lccc}
\hline Mice & Number & Age & nmole NANA/mg creatinine \\
\hline Controls & 4 & $2-8$ months & $1906 \pm 155$ (range 1663-2310) \\
Heterozygotes & 14 & $2-8$ months & $1905 \pm 117$ (range 993-2923) \\
Homozygotes & 21 & $2-5$ months & $7215 \pm 647$ (range 5305-19362) \\
& 7 & $6-8$ months & $27368 \pm 4845$ (range (11200-45763) \\
BMT-N & 1 & 5 months & $1812(5$ weeks; 3months p.t.) \\
BMT-TG & 4 & 5 months & 2114 (5 weeks; 8 weeks p.t.) \\
& & 5 months & 2106 (8 weeks 3 months p.t.) \\
& 5 months & 1799 (8 weeks; 9 weeks; 3 months p.t.) \\
& 2.5 months & 2011 (8 weeks; 9 weeks; 3 months p.t.)
\end{tabular}

Total sialyloligosaccharides were measured after acid hydroloysis of urine samples with thiobarinturic acid and were expressed in nmoles of released neuraminic acids per milligram of creatinine. (BMT-N) PPCA $(-/-)$ mice transplanted with bone marrow from a normal donor. (BMT-TG) PPCA $(-/-)$ mice transplanted with bone marrow from a transgenic mouse, overexpressing human protective protein in the erythroid lineage. Mice were transplanted at either 2.5 or 5 months of age. Sialyloligosaccharide determinations were performed at various time points post-transplantation (p.t.), as specified in parentheses. The values represent the mean of independent measurements. 


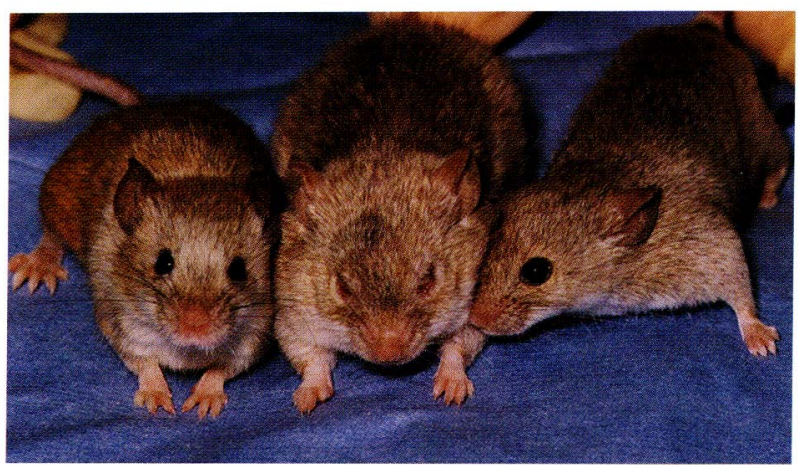

Figure 2. Gross phenotypic appearance of a PPCA $(-1-1$ mouse (middle) at 10 months of age, compared to a wild-type $(+1+\mid$ littermate $($ right $)$, and a $(-1-)$ littermate (left $)$ transplanted 5 months earlier with transgenic BM. The affected mouse has a broad face, disheveled coat, and swollen limbs and eyelids. In contrast, the BMT mouse clearly has improved in appearance. Evidence of edema has disappeared, and the coat is shiny and full.

gressively with age. The toluidine blue- and PAS-stained histological sections shown in Figure 4 were derived from a $(-1-)$ mouse at 6 month of age. In the affected kidney the epithelial cells of the proximal tubules were filled with swollen lysosomes. The glomeruli also were severely impaired by abundant vacuolation of parietal and visceral epithelium, endothelium and mesangial cells at this stage of the disease. Accumulation of undegraded material again was not apparent in the distal tubules. These abnormalities were not observed in control specimens, except for small resorption vesicles present normally at the apical side of the tubular epithelial cell surface (Fig. 4A). No evidence of storage was detected in the adrenal glands (not shown). In the $(-/-)$ liver, hepatocytes contained numerous, small membrane-bound vacuoles, whereas the Kupffer cells in the sinusoids were more affected and acquired the characteristic foamy appearance (Fig. 4A). Both hepatocytes and Kupffer cells stained positive with PAS + (not shown). The spleen of the diseased mouse showed extensive congestion of the sinuses and the marginal zones with foamy macrophages, which were also slightly PAS-positive. Furthermore, large cytoplasmic vacuoles were found in the lymphoid cells. Megakaryocytes were devoid of storage, despite their extensive lysosomal system (Fig. 4A).

The histopathology of the brain was examined in paraffin sections, and portions of the cerebrum and cerebellum were processed for frozen sections stained with PAS or for epoxy-resin sections stained with toluidine blue. Finely vacuolated storage cells similar to those found in the visceral organs also were observed in the brain. They often were located around neurons or blood vessels (Fig. $4 \mathrm{~B}, \mathrm{a}-\mathrm{c})$. Neuronal storage was rather inconspicuous on paraffin sections even in older mice. However, on frozen sections stained with PAS, affected neurons were identified easily by a brilliantly red storage material (Fig. 4B, d). Although frozen section study was carried out on lim- ited portions of the brain, there was a significant regional variation in the distribution of PAS-positive neurons. Entorhinal cortex and hippocampus appeared to be more involved (Fig. 4B, d) than the somatosensory cortex (Fig. $4 \mathrm{~B}$, e). In the cerebellum, there was a loss of Purkinje cells and some of the remaining Purkinje cells contained storage material in their perikarya (not shown). The granular cells were well preserved. Extensive storage was apparent in the epithelial and stromal cells of the choroid plexi (Fig. 5B, below). Finally, vacuolated cells were present in the trigeminal ganglia and the pituitary gland. The pituicytes also showed fine vacuolation (Fig. 4C).

Examination of other organs (i.e., pancreas, small and large intestine, lymph nodes, testis, ovaries, uterus, heart, bone marrow, and eye) confirmed the presence of membrane-bound vacuoles primarily in macrophages and cells of epithelial/endothelial origin (not shown). No evidence of lysosomal storage was detected in the lungs and skeletal muscles. The distribution and type of accumulating cells remained similar in 10-month-old mutant mice.

\section{Rescue of the galactosialidosis phenotype in the mouse model}

The rationale for using allogeneic BMT to treat lysosomal storage disorders is that progenitor bone marrow (BM) cells will repopulate the transplanted host and supply the missing enzyme to deficient cells in the tissues of the recipient. Correction takes place when the therapeutic enzyme secreted from normal BM cells is reinternalized by deficient cells, with restoration of lysosomal
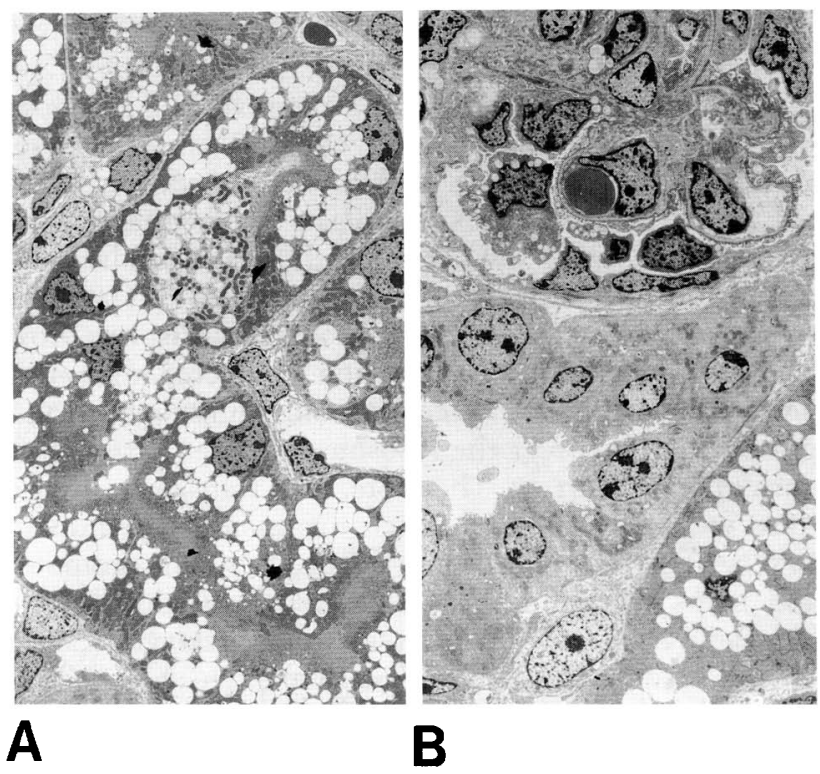

Figure 3. Electron microscopy of kidney from a 2-week-old $(-/-\mid$ mouse. $\{A \mid$ Micro- and macrovacuolation of the proximal tubules is apparent. $|B|$ Distal tubules and glomeruli are less, if not at all, affected at this stage of the disease. Magnification, $2000 \times(A)$ and $2500 \times$ for $(B)$. 


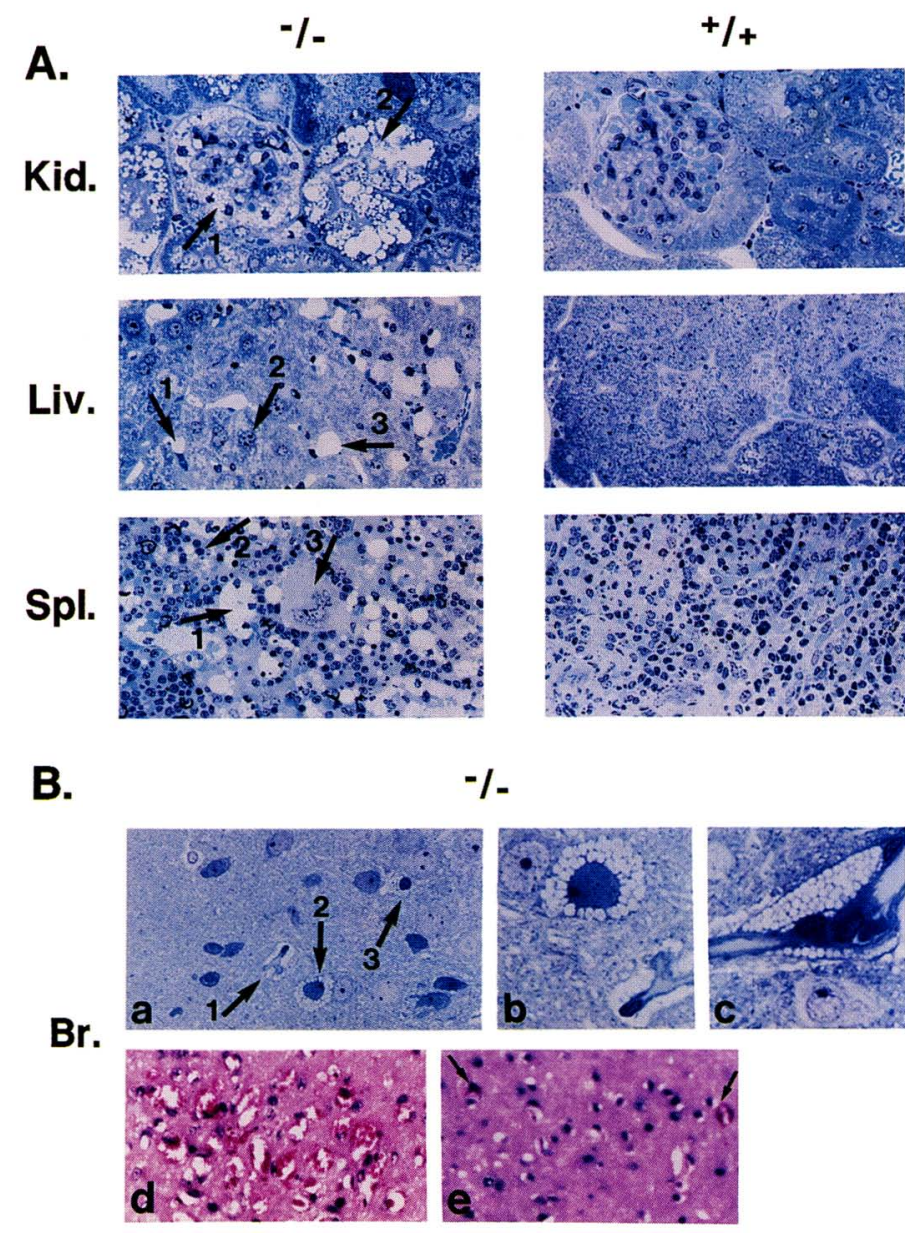

C.
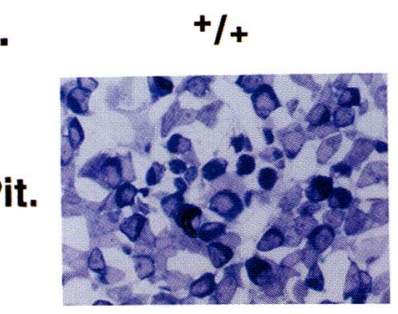

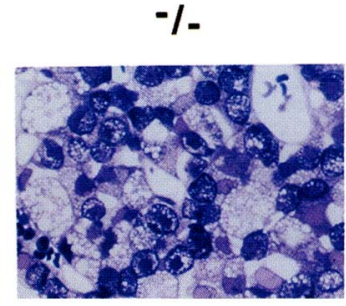

Figure 4. Histopathological analysis of a 6-month-old PPCA $(-1-)$ mouse compared to a $(+1+\mid)$ littermate. Semithin tissue sections from kidney (Kid.), liver (Liv.), spleen (Spl.), brain (Br.), and pituitary (Pit.) were stained with toluidine blue, whereas cryosections from the brain were stained with PAS. Morphological changes and extensive vacuolation of numerous cell types were detected, reflecting massive lysosomal storage. (A) (Original magnifications $400 \times$ ). In the kidney, arrows 1 and 2 indicate the vacuolation in glomeruli and proximal tubules, respectively; in the liver, 1 and 3 point to ballooned Kupffer cells, whereas 2 indicates microvacuolation of the hepatocyte. In the spleen, 1 and 2 show a vacuolated macrophage and lymphocyte, respectively, but a megakaryocyte is not affected (arrow 3). (B,a) (Magnification, $400 \times$ ). Some of the large neurons in the cerebral cortex have storage vacuoles (arrow 2) and endothelial and glial cells show extensive vacuolation (arrows 1 and 3 , respectively). $(B, b)$ A greater magnification $(1000 \times)$ of a selected area of $B, a$ whereas $B, c$ shows an enlarged perivascular cell $(1000 \times)$ with extensive storage vacuoles. $(B, d)$ (Magnification, $440 \times$ ). Neurons in the entorhinal cortex contain abundant PAS + storage material in their perikarya. (B,e) (Magnification, 400x). Only rare neurons conaining PAS + storage materials (arrows) are identified in the somatosensory cortex. (C) (Magnification, $880 \times$ ). Pituitary sland of the $(-1-)$ mouse shows vacuolation of pituicytes in addition to foamy macrophages.

function. It is conceivable that higher levels of the correcting protein will relate directly to more timely and effective treatment. We have shown previously that both human and murine PPCA precursors, selectively secreted by overexpressing cells, undergo endocytosis by cultured galactosialidosis fibroblasts via the mannose-6phosphate receptor and correct both $\beta$-galactosidase and neuraminidase activities (Galjart et al. 1991). Having a suitable animal model for galactosialidosis, we now could test whether transplantation of affected mice with BM cells overexpressing and secreting a functional PPCA protein could correct the lysosomal storage better than normal bone marrow. Therefore, four transgenic mouse lines were generated in which expression of a human PPCA transgene was driven by the $\beta$-globin promoter and locus control region (LCR) of the $\beta$-globin gene (Grosveld et al. 1987). The transgenic mice synthesized the heterologous human protein at high levels in cells of the erythroid lineage. Prior to transplantation, we ascertained that the product of the transgene also was secreted by BM cells to the extent that the high uptake precursor form of the protein was detectable in plasma and would undergo endocytosis by recipient cells. For this experiment, total BM cells derived from either transgenic or normal mice were cultured in the presence of cytokines for 5 days. The conditioned medium from these cultures, as well as serum from the same animals, was first assayed for $\alpha$-galactosidase, $\alpha$-glucosidase, and $\beta$-hexosaminidase activities (not shown) to ensure that overproduction of PPCA did not lead to aspecific release of other lysosomal proteins. Similar values for the three enzyme activities were measured in normal and transgenic samples, indicating that oversecretion of human PPCA was selective. Neuraminidase, being membrane bound, was not secreted and extracellular PPCA activity could not be tested because the precursor form of the protein is a zymogen, activated only in lysosomes. Conditioned media and sera then were added separately to deficient galactosialidosis cells from an early infantile patient (Galjart et al. 1988). As shown in Table 3, cathep$\sin \mathrm{A}, \beta$-galactosidase, and neuraminidase activities were clearly enhanced upon uptake of the human PPCA precursor from either BM-conditioned medium or directly from transgenic mouse serum. No significant increase in activity was detected in deficient fibroblasts treated with serum or BM-conditioned medium from normal mice. These results suggested that transgenic BM cells might achieve similar correction in vivo in affected mice.

Homozygous $(-/-)$ mice, ranging in age from 2.5 to 5 
Table 3. Uptake of BM-secreted human PPCA precursor by galactosialidosis fibroblasts and restoration of enzyme activities

\begin{tabular}{lccc}
\hline & $\begin{array}{c}\text { Cathepsin A } \\
\text { (nmole/min/mg) }\end{array}$ & $\begin{array}{l}\beta \text {-galactosidase } \\
\text { (nmole/hr/mg) }\end{array}$ & $\begin{array}{c}\text { Neuraminidase } \\
\text { (nmole/hr/mg) }\end{array}$ \\
\hline No addition & 2.1 & 66 & 0.05 \\
Normal serum & 3.3 & 78 & 0.1 \\
Normal BM-CM & 5.5 & 72 & 3.1 \\
TG serum & 31.2 & 186 & 14.5 \\
TG BM-CM & 51.2 & 216 & 13.5 \\
\hline
\end{tabular}

Conditioned media (CM) from cultured BM cells and serum samples, both derived from either normal or transgenic (TG) mice, were added to PPCA $(-/-)$ human galactosialidosis fibroblasts. After uptake, cell lysates were assayed for exogenous cathepsin A activitiy using the acylated dipeptide Z-Phe-Ala and for endogenous neuraminidase and $\beta$-galactosidase activities using synthetic 4-methylumbelliferyl substrates.

months, were lethally irradiated and transplanted, six with bone marrow from transgenic mice and six with bone marrow from normal mice. Both donor mouse lines were $\mathrm{T}$ cell depleted and were $\mathrm{H}-2 \mathrm{~B}$ compatible with the affected recipients. The repopulated mice were monitored for the level of storage material excreted in urine (Table 2). At 5 weeks after transplantation the total excretion of sialyloligosaccharides already was reduced to normal values, indicating that the PPCA provided by both transgenic and normal BM cells was sufficient to correct the accumulation of these storage products in urine. Furthermore, gross examination of transplanted animals, starting at 3 months post-BMT, showed complete reversal of the diseased phenotype, as exemplified by the 10-month-old mouse shown in Fig. 2 (left), transplanted 5 months earlier with transgenic bone marrow.

\section{Histopathology of transplanted mice}

Tissue sections from kidney, liver, spleen, intestine, heart, lymph nodes, and brain of two $(-/-)$ mice transplanted with bone marrow from either transgenic (BMT$\mathrm{Tg}$ ) or normal donors (BMT-N) were compared with similar sections from normal and untreated littermates 3 months after transplantation. As shown in Fig. 5A, the abnormalities in the proximal tubular epithelium in the kidney of the BMT-N mouse were resolved practically, whereas storage vacuoles were still abundant in the glomerular epithelium. These aberrant features still persisted in similarly treated mice examined 2 months later. In contrast, kidney specimens of the BMT-Tg mouse showed complete reversal of the diseased phenotype, even within the glomeruli, indicating that a higher dose of normal enzyme had a more beneficial and immediate effect on this severely affected tissue. Clearance of storage material and normalization of cellular morphology was apparent from the liver of mice treated either with normal or transgenic bone marrow (Fig. 5A). However, Kupffer cells with some vacuoles were encountered infrequently in liver sections of the BMT-N mouse, but not in corresponding sections of the BMT- $\mathrm{Tg}$ mouse. As expected, spleen (Fig. 5A) as well as bone marrow specimens appeared completely normal. Most of the abnormalities in the colon, jejunum, and duodenum were cor- rected, though the autonomic ganglia still showed a lesser degree of storage. In the heart vacuolated endothelial cells and foamy histiocytes were no longer encountered. The lymph nodes of both types of transplanted mice had a normal appearance with no evidence of accumulation of foamy macrophages, although storage in occasional lymphoid cells was seen only in the specimens from the BMT-N mice (not shown). In the brain of BM-transplanted mice storage neurons and perivascular as well as perineural vacuolated cells still could be identified (not shown). However, further quantitative assessment is necessary to evaluate the effect of the BM transplant in the brain. On the other hand, vacuolated cells in the choroid plexi (Fig. 5B), the trigeminal ganglia, and the pituitary had disappeared completely in both transplanted mice.

In conclusion, reversal of the diseased phenotype clearly was significant in BMT-N mice but was more complete in BMT-Tg animals, supporting the idea that the release of a higher level of enzyme by overproducing donor BM cells is likely to be more effective for treatment.

\section{Discussion}

Molecular and biochemical characteristics of PPCA $(-/-)$ mice correlate well with the most severe form of galactosialidosis in humans. Although viable and fertile, deficient mice present signs of illness very early in life with clear evidence of metabolic storage in cells from different organs. The edema, visceromegaly, and coarse face noticed in $(-1-)$ animals are abnormalities characteristic of the human disease phenotype. Nephropathy, which is a major complication and cause of death in early infantile patients (d'Azzo et al. 1995), is also the most apparent cause of physical deterioration in affected mice. Discrepancy in the severity of the disease between early infantile patients and young affected mice may be attributed simply to the much shorter gestation period of mice because the pathology of lysosomal disorders is largely associated with progressive accumulation of undegraded products in lysosomes, leading eventually to cellular dysfunction. The greater longevity of affected mice relative to human patients could also relate to the observed higher levels of $\beta$-galactosidase in some of the 

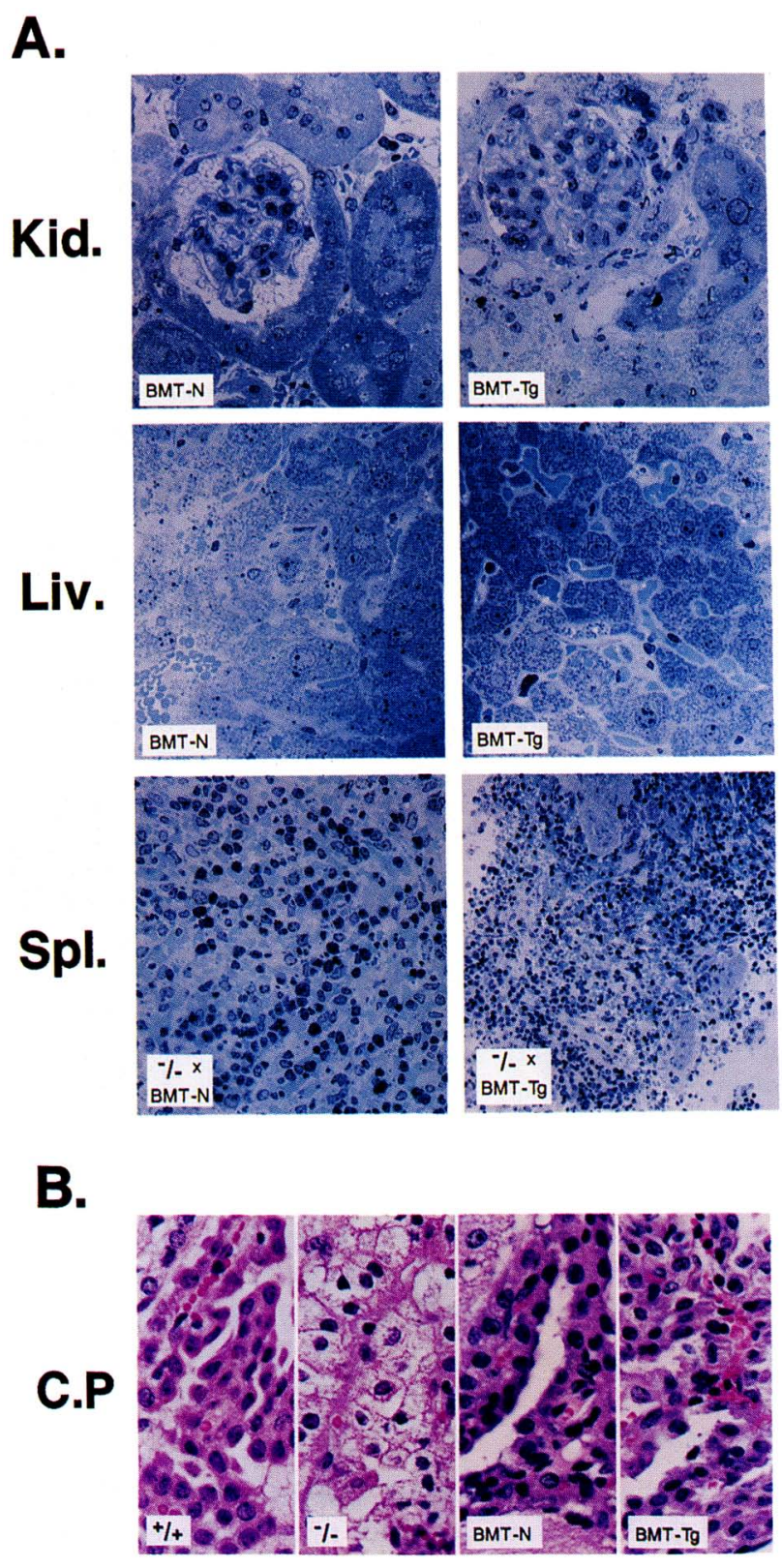

Figure 5. Histology of BMT mice. (A) Sections from the kidney (Kid.), liver (Liv.), and spleen (Spl.) of a $(-/-)$ mouse transplanted with either BMT-N or BMT-Tg were stained with toluidine blue (magnification, $400 \times$ ). In the BMT-N kidney, storage vacuoles still are apparent in the glomerular epithelium. In contrast, the BMT-Tg kidney shows complete correction of the lesions. In both BMT-N and BMT-Tg mice, the liver and the spleen show normal cellular morphology. However, in the BMT-N mouse, some of the Kupffer cells still are slightly vacuolated. $(B)$ Haematoxylin/eosin-stained paraffin sections (magnification, $400 \times 1$ of the choroid plexus from normal, affected, and transplanted mice. Storage in the epithelial cells of the $(-/$ - ) animal is signified by the dispersed staining of the cytoplasm. This aberration is reversed completely by transplantation with normal or transgenic BM.

affected mouse tissues. Alternatively, but not exclusive of the first two, the difference may be caused by speciesspecific variation in substrate metabolism. Similar ex- planations may account for divergence in time of development of the diseased phenotype for mice and humans with hexosaminidase A deficiency (Yamanaka et al. 1994). Thus, in spite of the longer survival, galactosialidosis mice are affected severely and can be considered a faithful model for the human disease.

The deficiency of PPCA in tissues of mutant mice is accompanied by an equivalent loss of lysosomal neuraminidase activity, whereas $\beta$-galactosidase values are variable. Although in murine $(-/-)$ fibroblasts the residual $\beta$-galactosidase activity is consistent with that measured in patients' cells (d'Azzo et al. 1995), in other tissues the activity is either only slightly reduced or higher than normal levels. This finding may again reflect differences between species, although equivalent data for galactosialidosis patients are scarce, as autopsies are limited to a few cases from adult Japanese patients (Amano et al. 1983; Suzuki et al. 1984). The mouse results may be in line with earlier purification and coprecipitation studies, indicating that only a fraction of the $\beta$-galactosidase and PPCA in mammalian tissues exists in the associated mode, whereas all neuraminidase activity is detected in complex with the other two enzymes (Verheijen et al. 1985; Galjart et al. 1991; Hubbes et al. 1992). Thus, it is possible that in different murine cell types, $\beta$-galactosidase is stable whether or not associated with PPCA, whereas the interaction of neuraminidase with PPCA clearly is essential for its activity. The consequences of the severe neuraminidase, rather than $\beta$-galactosidase, deficiency are reflected in the type of storage products present in urine of the $(-1-1$ mice, which are mainly sialylated oligosaccharides, as observed in human patients (Amano et al. 1983; van Pelt et al. 1989).

The pathological findings in the PPCA-deficient mice are consistent with those reported for galactosialidosis patients. Epithelial cells, endothelial cells, and macrophages are the first to show lesions in most organs, and the distribution of storage appears similar to that observed in the Gaucher and Nieman Pick mouse models (Tybulewicz et al. 1992; Horinouchi et al. 1995; Otterbach and Stoffel 1995). The type and number of vacuolated cells in galactosialidosis mice gradually increase with age. However, not all cells become affected and the extent of the damage is variable, even in older $|-|-\mid$ animals. The profiles may depend on the metabolic state of the cells and the type of substrates to be catabolized, in particular by neuraminidase. Alternatively, it may reflect a microheterogeneity in the distribution of the normal protein in different cell types. We have shown previously that the protective and catalytic functions of PPCA are fully separable (Galjart et al. 1991), but the physiological significance of the cathepsin A activity is still unclear. We can speculate that in certain cells the protein exerts its activity outside the lysosomal complex. In this case, loss of catalytic activity may not result in lysosomal storage. Perhaps evidence of a functional lesion will be found when knockout mice are screened for symptoms associated with loss of cathepsin A activity on peptides (e.g., substance $P$, oxytocin, or endothelin I), which may be substrates of the protein in vivo. 
The most striking results of this study are those obtained with BMT. The main aim for generating a mouse model for galactosialidosis was to evaluate therapeutic strategies that could be applicable to genetic correction of this and other similar disorders in humans. The possibility of manipulating autologous hematopoietic progenitor cells in vitro that will express constitutively the correcting enzyme at high levels in the repopulated recipient has important implications for somatic gene therapy of lysosomal disorders with CNS involvement. Transfer and expression of foreign genes into animal and human hematopoietic cells, as well as other cell types, has been achieved using different viral vectors (for review, see Kay and Woo 1994). In designing a therapeutic approach for our galactosialidosis mouse model, we started with the supposition that the amount of normal enzyme (supplied by BM cells) would be crucial for effective correction. Thus, we have analyzed the consequences of transplanting PPCA $(-/-)$ mice with BM cells, derived from a transgenic line overexpressing the normal protein in a specific hematopoietic lineage. By analogy with other heterologous genes (van Assendelft et al. 1989; Needham et al. 1992), the LCR and $\beta$-globin cassette (used in this study) promote high expression of PPCA in erythroid precursor cells in a copy number-dependent, position-independent fashion. Overexpression of the transgene results in the extracellular release of PPCA precursor that is readily taken up by deficient human cells via a mannose-6-phosphate-mediated endocytosis. Hyper secretion is selective for the product of the transgene, as observed previously for other lysosomal enzymes overexpressed in various cell types (Ioannou et al. 1992; Grubb et al. 1993; Kakkis et al. 1994). BMT has proven to be very effective for improvement of the diseased phenotype. Treated PPCA $(-/-)$ animals look completely normal and outlive the affected mice. Analysis of their tissues demonstrates that transplantation of the overexpressing bone marrow clearly is more effective than normal bone marrow for clearing storage in cells of visceral organs that undergo complete reversal of the lesions. The most plausible explanation of these data is that erythroid precursor cells secrete sufficient amounts of a stable PPCA precursor into the plasma to permit its ready uptake by cells in distant organs. Correction in the CNS, which mostly excludes plasma proteins because of the blood-brain barrier, is less evident but still noticeable, especially in the epithelial cells of the choroid plexi. This is likely attributable to internalization of the heterologous human protein from the plasma via the mannose-6-phosphate receptor (Nilsson et al. 1992) and/ or the murine protein from donor-derived monocytes and perivascular macrophages. Detailed evaluation of the degree of CNS correction awaits fine mapping of the affected cells in different regions of the brain, which is currently in progress, and the analysis of a larger number of treated mice. Our findings conform in part with the results obtained with BMT in cats with the lysosomal storage disorder $\alpha$-mannosidosis (Walkley et al. 1994a), another disorder of glycoprotein metabolism. These investigators report a clear improvement of the CNS le- sions, but its extent is unclear, as no detailed spatial mapping of the storage neurons was presented. To improve the correction of the CNS, we currently are testing whether transgenic bone marrow with targeted expression of PPCA in the monocyte/macrophage lineage would be more effective. Transplantation of young animals with such transgenic bone marrow is expected to be more beneficial because donor-derived monocytes and macrophages can become part of the microglial population (Perry et al. 1985; Hickey and Kimura 1988).

Although galactosialidosis affects only a small proportion of the population, it has devastating consequences in children, with the early infantile form of the disease resulting in early death, multiple organ dysfunction, and mental retardation. There are, however, a limited number of patients, some of them diagnosed recently, in which the disease does not impair the CNS. Our findings indicate that somatic gene therapy approaches using autologous human BM cells, which continuously express the correcting enzyme at high levels, may be feasible in the future as a cure of galactosialidosis, especially in mildly affected children. Moreover, they set the stage for the use of this approach in other lysosomal storage diseases.

\section{Materials and methods \\ Construction of the PPCA targeting vector}

A mouse genomic clone encompassing the entire coding region of the PPCA gene was isolated from an EMBL-3 $\lambda$ phage library constructed with DNA from the CCE ES cell line derived from mouse strain 129Sv. PPCA DNA sequences contained in a 14$\mathrm{kb}$ Sall fragment were identified by restriction mapping and partial sequencing of exons. From this clone a 10-kb EcoRI-SalI fragment was subcloned into pTZ18 and used to generate the targeting vector. The hygro cassette (van Deursen and Wieringa 1992) was inserted into exon 2 of the PPCA gene, 6 nucleotides downstream of the ATG start codon (see Fig. 1). In the resulting targeting vector, the hygro gene was flanked $5^{\prime}$ and $3^{\prime}$ by 3 and $7 \mathrm{~kb}$ of homologous sequences, respectively. A $2.0-\mathrm{kb}$ Sall fragment of the herpes simplex virus thymidine kinase (HSV-TK) cassette was positioned $3^{\prime}$ of the construct, outside the region of homology. Both positive and negative selectable markers were inserted in the antisense orientation with respect to the transcriptional orientation of the PPCA gene and were driven by the $\mathrm{TK}$ promoter and PyF441 polyoma enhancer.

\section{Gene targeting in ES cells}

The 129/Ola-derived ES cell line E14 (a gift of Anton Berns, The Netherlands Cancer Institute, Amsterdam) was maintained in $60 \%$ Buffalo rat liver (BRL)-conditioned Dulbecco's modified Eagle medium (DMEM) $/ 40 \%$ fresh DMEM, 15\% fetal bovine serum (FBS), $0.1 \mathrm{mM}$ 2-mercaptoethanol, $2 \mathrm{~mm}$ glutamine, and $1000 \mathrm{U} / \mathrm{ml}$ of leukemia inhibiting factor (GIBCO). The cells were trypsinized, resuspended at a concentration of $10^{7} / \mathrm{ml}$ in PBS, and electroporated at room temperature with $25 \mu \mathrm{g}$ of SalI linearized vector DNA at $117 \mathrm{~V}$ and $1200 \mu \mathrm{F}$ for $10 \mathrm{msec}$, using a Progenetor II gene pulser (Hoeffer). After electroporation, cells were kept on ice for $10 \mathrm{~min}$ and transferred onto $10-\mathrm{cm}$ culture dishes coated with $0.1 \%$ gelatin in above medium. After recovery for $24 \mathrm{hr}$, cells were put on selection medium containing 188 
$\mu \mathrm{g} / \mathrm{ml}$ of hygromycin B (Calbiochem) and $0.2 \mu \mathrm{M}$ FIAU (1-[2deoxy, 2-fluoro- $\beta$-D-arabinofuranosyll-5 iodouracil, a kind gift of Bristol Myers) for 7-10 days. Resistant colonies were expanded in 24-well plates; half of the cells in each well was cryopreserved, and the other half was expanded for genotype analysis. Positive clones were stored in liquid nitrogen and thawed at least 3 days before blastocyst injection.

\section{Generation of mutant mice}

Blastocysts were isolated at day 3.5 postcoitum by flushing the uterine horns of naturally mated C57BL/ 6 pregnant females with DMEM plus $10 \%$ FBS. Approximately 10-15 ES cells from each homologous recombinant clone carrying 40 chromosomes were microinjected into recipient blastocysts, and 9-14 embryos were transferred into the uterine horns of $(\mathrm{C} 57 \mathrm{BL} /$ $6 \times \mathrm{CBA} / \mathrm{Ca}$ ) $\mathrm{F}_{1}$ pseudopregnant fosters (Bradley 1987). Chimeric males were mated with $\mathrm{C} 57 \mathrm{BL} / 6$ or $\mathrm{FVB} / \mathrm{J}$ females, and germline transmission of the mutant allele was verified by Southern blot analysis of tail DNA from $F_{1}$ offspring with either agouti or gray coat color. $F_{2}$ offspring from interbred heterozygotes was genotyped by Southern blotting to identify homozygous null mutants. The phenotypic alterations in PPCA $(-1-)$ mice, as presented in this paper, were uniform and showed complete penetrance, irrespective of their genetic background.

\section{Southern and Northern Blot Analyses}

Genomic DNA isolated from ES cells or mouse tails was digested with NdeI, resolved on a $0.8 \%$ agarose gel, and transferred onto Hybond-N + membranes (Amersham). The $5^{\prime}$ junction was checked by hybridization with a 1-kb EcoRI-NdeI probe positioned immediately $5^{\prime}$ of the targeting construct, and the $3^{\prime}$ junction was checked with a $0.5-\mathrm{kb}$ PCR probe positioned immediately $3^{\prime}$ of the targeting construct. Absence of additional random integrations of the targeting construct was checked with a hygro probe. Clones that contained the expected $5-\mathrm{kb}$ NdeI fragment, diagnostic for homologous recombination, were obtained at a frequency of 1 in 7. For genotype analysis of tail DNA, only the $5^{\prime}$ probe was used. Total RNA was isolated from brain, kidney, and liver tissues of 4-to 6-week-old mice as described (Auffray and Rougeon 1980). RNA (15-20 $\mu \mathrm{g}$ ) was separated on a $1 \%$ agarose gel containing $0.66 \mathrm{M}$ formaldehyde. After electrophoresis, the RNA was blotted onto a Zeta-probe membrane (Bio-Rad) and hybridized with the mouse cDNA probe.

\section{Enzyme activity assays and urine oligosaccharide determinations}

For enzyme activity assays, primary cultures of skin fibroblasts and tissues from affected and normal mice were homogenized in double-distilled water. Cathepsin A activity was measured with the synthetic dipeptide substrate Z-Phe-Ala, according to the procedure described earlier (Galjart et al 1991). The activities of $\beta$-galactosidase and neuraminidase were assayed with artificial 4-methylumbelliferyl substrates (Galjaard 1980). Total protein concentration was determined using the method of Smith et al. (1985). Total sialic acid content in urine was measured in $10 \mu \mathrm{l}$ samples after hydrolysis in $0.1 \mathrm{~N} \mathrm{H}_{2} \mathrm{SO}_{4}$ by a modification of the method of Aminoff (1961), as described in Wenger and Williams (1991). $\mathrm{N}$-acetylneuraminic acid was used as a standard. Creatinine was measured in a fraction of each sample by the central diagnostic laboratory of Thomas Jefferson University (Philadelphia, PA).

\section{Histopathological analyses}

Tissues isolated from affected and BM-treated mice as well as normal or heterozygous littermates were fixed with $2 \%$ glutaraldehyde in $0.2 \mathrm{M}$ phosphate buffer, postfixed with $1 \%$ osmium tetroxide in $0.2 \mathrm{M}$ phosphate buffer, dehydrated in graded ethanol ( $70 \%$ through absolute), en bloc stained with $4 \%$ uranyl acetate in absolute ethanol, and embedded in Spurr resin (Ladd Research Industries, Inc., Burlington, VT). Semithin sections were cut at $470 \mathrm{~nm}$ and stained with toluidine blue for light microscopy. Sections for electron microscopy were cut at $85 \mathrm{~nm}$ and stained with $2 \%$ uranyl acetate/lead citrate and screened with JEOL 1200 EX II (JEOL USA Inc., Peabody, MA). For preparation of paraffin sections, dissected tissues were fixed overnight in $10 \%$ formalin. After dehydration and paraffin embedding, 6- $\mu \mathrm{m}$ sections were made, mounted on slides, and stained with haematoxylin/eosin. For the analysis of the brain, affected and BM-treated mice were perfused through the left cardiac ventricle with $4 \%$ paraformaldehyde in PBS. The cerebrum was sectioned coronally at the level of the optic chiasm. The anterior half of the cerebrum, cerebellum, and brainstem were processed for paraffin embedding, sectioned $6 \mu \mathrm{m}$ thick, and stained solochrome/eosin and luxol fast blue (LFB)/ PAS. The posterior half was cryosectioned serially at $10 \mu \mathrm{m}$ thick and stained with PAS. The trigeminal ganglia and pituitary gland were postfixed with osmium and processed for epoxy-resin embedding as described above.

\section{Uptake in galactosialidosis fibroblasts}

$\mathrm{BM}$ cells from three normal and three transgenic mice were harvested by flushing the femurs with DMEM and 15\% FBS. Cells were washed once with the same medium and seeded at a concentration of $1.5 \times 10^{6} / \mathrm{ml}$ in three $30 \mathrm{~mm}$ dishes. Then they were cultured for an additional 5 days in the above medium supplemented with $10 \mathrm{U} / \mathrm{ml}$ of erythropoietin (Amgen, Inc). The conditioned medium from each culture then was pooled and added to confluent galactosialidosis fibroblasts from an early infantile patient, seeded 5 days in advance in six-well plates. In parallel, serum samples from the same mice were also pooled, concentrated, and added to the deficient cells. Uptake was carried out for 4 days. Treated fibroblasts then were harvested by trypsinization and homogenized for enzymatic assays as above.

\section{BM transplantation}

The recipient galactosialidosis mice at 2.5-5 months of age were lethally irradiated with $9.25 \mathrm{~Gy}$ from a cesium irradiator, $24 \mathrm{hr}$ before transplant. Normal BM was derived from two C57BL/6 Thyl.1 mice. Transgenic BM was derived from two mice of a $(\mathrm{C} 57 \mathrm{Bl} / 6 \times \mathrm{CBA}) \mathrm{F}_{1}$ transgenic line in which the human protective protein precursor is overexpressed in the erythroid lineage under the control of the $\beta$-globin promoter and LCR. BM cells were harvested by flushing the femurs with Hanks medium with 5\% FBS. Prior to BMT, donor cells were incubated with HO-22-1 and AT 83 antibodies for $15 \mathrm{~min}$ to deplete the T-cell population. A cell suspension $(0.5 \mathrm{ml})$ containing $2 \times 10^{7}$ cells $/ \mathrm{ml}$ was injected intravenously into the tail vein. Starting at 3 months post-transplantation, tissues from both normal and transgenic BM-treated mice were isolated and prepared for light microscopy, as described above.

\section{Acknowledgments}

We are indebted to Professor Hans Galjaard and the Foundation of Clinical Genetics at the Erasmus University in Rotterdam for 
support and funding part of this project. We thank Martine Jeaglé (Department of Genetics, Erasmus University, Rotterdam) for initiating X.Y.Z. to blastocyst injection; Jan van Deursen for technical advice, for the hygromycin and TK cassettes, and for critical reading of this manuscript ${ }_{j}$ and Judith Boer and Aarnoud van der Spoel for useful suggestions and help in the culture of BM cells. We are grateful to Jerry Rehg and his staff for the assistance in the animal facility and John Zacher, Linda Rawlinson, and their collaborators at the Biomedical Communications (BMC) department for the excellent art and photography work. We thank Sjozef van Baal for the computer graphic work and Peggy Burdick for editing this manuscript. A.d.A. dedicates this work to Vincenzo d'Azzo. These studies were supported in part by the Cancer Center CORE Grant and the American Lebanese Syrian Associated Charities (ALSAC) of St. Jude Children's Research Hospital.

The publication costs of this article were defrayed in part by payment of page charges. This article must therefore be hereby marked "advertisement" in accordance with 18 USC section 1734 solely to indicate this fact.

\section{References}

Ahern-Rindell, A.J., D.J. Prieur, R.D. Murnane, S.S. Raghavan, P.F. Daniel, R.H. McCluer, S.U. Walkley, and S.M. Parish. 1988. Inherited lysosomal storage disease associated with deficiencies of $\beta$-galactosidase and $\alpha$-neuraminidase in sheep. Am. I. Med. Genet. 31: 39.

Amano, N., S. Yokoi, M. Akagi, M. Sakai, S. Yagishita, and K. Nakata. 1983. Neuropathological findings of an autopsy case of adult $\beta$-galactosidase and neuraminidase deficiency. Acta Neuropathol. 61: 283-290.

Aminoff, D. 1961. Methods for the quantitative estimation of $\mathrm{N}$-acetylneuraminic acid and their application to hydrolysates of sialomucoids. Biochem. I. 81: 384-392.

Auffray, C. and F. Rougeon. 1980. Purification of mouse immunoglobin heavy chain messenger RNAs from total myeloma tumor RNA. Eur. J. Biochem. 107: 303-314.

Birkenmeier, E.H., J.E. Barker, C.A. Vogler, J.W. Kyle, W.S. Sly, B. Gwynn, B. Levy, and C. Pegors. 1991. Increased life span and correction of metabolic defects in murine MPS VII following syngeneic bone marrow. Blood 78: 3081 .

Bradley, A. 1987. Production and analysis of chimeric mice. In Teratocarcinomas and embryonic stem cells: A practical aproach (ed. E.J. Robertson), pp. 113-151. IRL Press, Oxford, UK.

d'Azzo, A., A. Hoogeveen, A.J. Reuser, D. Robinson, and H. Galjaard. 1982. Molecular defect in combined beta-galactosidase and neuraminidase deficiency in man. Proc. Natl. Acad. Sci. 79: 4535-4539.

d'Azzo, A., G. Andria, P. Strisciuglio, and H. Galjaard. 1995. Galactosialidosis. In The metabolic and molecular bases of inherited disease (ed. C.R. Scriver, A.L. Beaudet, W.S. Sly, and D. Valle), Vol. 2, pp. 2825-2838. McGraw-Hill, New York.

Dobrenis, K., D.A. Wenger, and S.U. Walkley. 1994. Extracellular release of lysosomal glycosidases in cultures of cat microglia (Abst. 652). Mol. Biol. Cell 5: 113a.

Galjaard, H. 1980. Genetic metabolic disease: Diagnosis and prenatal analysis. Elsevier Science Publishers, B.V., Amsterdam, The Netherlands.

Galjart, N.J., N. Gillemans, A. Harris, G.T.J. van der Horst, F.W. Verheijen, H. Galjaard, and A. d'Azzo. 1988. Expression of cDNA encoding the human "protective protein" associated with lysosomal beta-galactosidase and neuraminidase: Ho- mology into yeast proteases. Cell 54: 755-764.

Galjart, N.J., H. Morreau, R. Willemsen, N. Gillemans, E.J. Bonten, and A. d'Azzo. 1991. Human lysosomal protective protein has cathepsin A-like activity distinct from its protective function. J. Biol. Chem. 266: 14754-14762.

Grosveld, F., G. Blom van Assendelft, D.R. Greaves, and G. Kollias. 1987. Position-independent, high-level expression of the human $\beta$-globin gene in transgenic mice. Cell 51: 975985.

Grubb, J.H., J.W. Kyle, L.B. Cody, and W.S. Sly. 1993. Large scale purification of phosphorylated recombinant human $\beta$-glucoronidase from overexpressing mouse $\mathrm{L}$ cells. FASEB I. 7: A1255.

Hanna, W.L., J.M. Turbov, H.L. Jackman, F. Tan, and C.J. Froelich. 1994. Dominant chymotrypsin-like esterase activity in human lymphocyte granules is mediated by the serine carboxypeptidase called cathepsin A-like protective protein. I. Immunol. 153: 4663-4672.

Haskins, M., H.J. Baker, E. Birkenmeier, P.M. Hoogerbrugge, B.J.H.M. Poorthuis, T. Sakiyama, R.M. Shull, R.M. Taylor, M.A. Thrall, and S.U. Walkley. 1991. Transplantation in animal model systems. In Treatment of genetic diseases, pp. 183-201. Churchill Livingstone, New York.

Hickey, W.F. and H. Kimura. 1988. Perivascular microglial cells of the CNS are BM-derived and present antigen in vivo. Science 239: 290-292.

Hoogerbrugge, P.M., O.F. Brouwer, P. Bordigoni, O. Ringden, P. Kapaun, J.J. Ortega, A. O'Meara, G. Cornu, G. Souillet, D. Frappaz, S. Blanche, and A. Fischer. 1995. Allogeneic bone marrow transplantation for lysosomal storage disorders. Lancet 345: 1398-1402.

Hoogeveen, A.T., F.W. Verheijen, and H. Galjaard. 1983. The relation between human lysosomal beta-galactosidase and its protective protein. J. Biol. Chem. 258: 12143-12146.

Horinouchi, K., S. Erlich, D.P. Perl, K. Ferlinz, C.L. Bisgaier, K.Sandoff, R.J. Desnick, C.L. Stewart, and E.H. Schuchman. 1995. Acid sphingomyelinase deficient mice: A model of types A and B Niemann-Pick disease. Nature Genet. 10: 288-293.

Hubbes, M., R.M. d'Agrosa, and J.W. Callahan. 1992. Human placental $\beta$-galactosidase. Characterization of the dimer and complex forms of the enzyme. Biochem. J. 285: 827-831.

Ioannou, Y.A., D.F. Bishop, and R.J. Desnick. 1992. Overexpression of human $\beta$-galactosidase A results in its intracellular aggregation, crystallization in lysosomes and selective secretion. J. Cell Biol. 119: 1137-1150.

Jackman, H.L., F.L. Tan, H. Tamei, C. Buerling-Harbury, X.Y. Li, R.A. Skidgel, and E.G. Erdos. 1990. A peptidase in human platelets that deamidates tachykinins: Probable identity with the lysosomal "protective protein". I. Biol. Chem. 265: 11265-11272.

Jackman, H.L., P.W. Morris, P.A. Deddish, R.A. Skidgel, and E.G. Erdos. 1992. Inactivation of endothelin I by deamidase (lysosomal protective protein). I. Biol. Chem. 267: 28722875.

Kakkis, E.D., A. Matynia, A.J. Jonas, and E.F. Neufeld. 1994. Overexpression of the human lysosomal enzyme $\alpha$-L-iduronidase in Chinese hamster ovary cells. Protein Expr. Purif. 5: 225-232.

Kay, M.A. and S.L. Woo. 1994. Gene therapy for metabolic disorders. Trends Genet. 10: 253-257.

Knowles, K., J. Alroy, M. Castagnaro, S.S. Raghavan, R.M. Jakowski, and G.O. Freden. 1993. Adult-onset lysosomal storage disease in a Schipperke dog: Clinical, morphological and biochemical studies. Acta Neuropathol. 86: 306-312.

Krivit, W., E. Shapiro, P.M. Hoogerbrugge, and H.W. Moser. 
1992. State of the art review: BM transplantation treatment for storage diseases. Bone Marrow Transplant 10: 87 .

Moullier, P., D. Bohl, J. Cardoso, J.M. Heard, and O. Danos. 1995. Long-term delivery of a lysosomal enzyme by genetically modified fibroblasts in dogs. Nature Med. 1(4): 353357.

Needham, M., C. Gooding, K. Hudson, M. Antoniou, F. Grosveld, and M. Hollis. 1992. LCR/MEL: A versatile system for high-level expression of heterologous proteins in erythroid cells. Nucleic Acids Res. 20: 997-1003.

Nilsson, C., P. Blay, F.C. Nielsen, and S. Gammeltoft. 1992. Gene expression and receptor binding of insulin-like growth factor-II in pig choroid plexus epithelial cells. J. Neurochem. 58: $923-930$.

Okada, S., T. Kato, S. Miura, H. Yabuuchi, M. Nishigaki, A. Kobata, H. Chiyo, and J. Furuyama. 1978. Hypersialyloligosacchariduria in mucolipidosis: A method for diagnosis. Clin. Chim. Acta 86: 159-167.

Otterbach, B. and W. Stoffel. 1995. Acid sphinghomyelinasedeficient mice mimic the neurovisceral form of human lysosomal storage disease (Niemann-Pick disease). Cell 81: 1053-1061.

Perry, V.H., D.A. Hume, and S. Gordon. 1985. Immunohistochemical localization of macrophages and microglia in the adult and developing mouse brain. Neuroscience 15: 313-326.

Potier, M., L. Michaud, J. Tranchemontagne, and L. Thauvette. 1990. Structure of the lysosomal neuraminidase-beta-galactosidase-carboxypeptidase multienzymic complex. Biochem. I. 267: 197-202.

Rawlings, N.D. and A.J. Barrett. 1994. Families of serine peptidases. Methods Enzymol. 244 19-61.

Scheibe, R., K. Hein, and K.W. Wenzel. 1990. Lysosomal betagalactosidase from rat liver: Purification, molecular forms and association with neuraminidase. Biomed. Biochim. Acta 49: 547-556.

Smith, P.K., R.I. Krohn, G.T. Hermanson, A.K. Mallia, F.H. Gartner, M.D. Provenzano, E.K. Fujimoto, N.M. Goeke, B.J. Olson, and D.C. Klenk. 1985. Measurement of protein using bicinchoninic acid [published erratum appears in Anal Biochem 163:279. 1987]. Anal Biochem. 150: 76-85.

Snyder, E.Y., R.M. Taylor, and J.H. Wolfe. 1995. Neural progenitor cell engraftment corrects lysosomal storage throughout the MPS VII mouse brain. Nature 374: 367-374.

Suzuki, Y., H. Sakuraba, T. Yamanaka, Y.M. Ko, Y. Imori, Y. Okamura, and A.T. Hoogeveen. 1984. Galactosialidosis: A comparative study of clinical and biochemical data on 22 patients. In The developing brain and its disorders (ed. $M$. Arima, Y. Suzuki, and H. Yabuuchil, pp. 161-175. University of Tokyo Press, Tokyo, Japan.

Tybulewicz, V.L.J., M.L. Tremblay, M.E. LaMarca, R. Willemsen, B.K. Stubblefield, S. Winfield, zb. Zablocka, E. Sidransky, B.M. Martin, S.P. Huang, K.A. Mintzer, H. Westphal, R.C. Mulligan, and E.I. Ginns. 1992. Animal model of Gaucher's disease from targeted disruption of the mouse glucocerebrosidase gene. Nature 357: 407-410.

van Assendelft, G.B., O. Hanscombe, F. Grosveld, and D.R. Greaves. 1989. The $\beta$-globin dominant control region activates homologous and heterologous promoters in a tissuespecific manner. Cell 56: 969-977.

van der Horst, G., N.J. Galjart, A. d'Azzo, H. Galjaard, and F.W. Verheijen. 1989. Identification and in vitro reconstitution of lysosomal neuraminidase from human placenta. J. Biol. Chem. 264: 1317-1322.

van Deursen, J. and B. Wieringa. 1992. Targeting of the creatine kinase $M$ gene in embryonic stem cells using isogenic and nonisogenic vectors. Nucleic Acids Res. 29: 3815-3820. van Pelt, J., J.P. Kamerling, J.F. Vliegenthart, A.T. Hoogeveen, and H. Galjaard. 1988a. A comparative study of the accumulated sialic acid-containing oligosaccharides from cultured human galactosialidosis and sialidosis fibroblasts. Clin. Chim. Acta 174: 325-335.

van Pelt, J., J.A. van Kuik, J.P. Kamerling, J.F. Vliegenthart, O.P. van Diggelen, and H. Galjaard. 1988b. Storage of sialic acidcontaining carbohydrates in the placenta of a human galactosialidosis fetus. Isolation and structural characterization of 16 sialyloligosaccharides. Eur. J. Biochem. 177: 327-338.

van Pelt, J., K. Hard, J.P. Kamerling, J.F. Vliegenthart, A.J. Reuser, and H. Galjaard. 1989. Isolation and structural characterization of twenty-one sialyloligosaccharides from galactosialidosis urine. An intact N, N'-diacetylchitobiose unit at the reducing end of a diantennary structure. Biol. Chem. Hoppe-Seyler 370: 191-203.

Verheijen, F., R. Brossmer, and H. Galjaard. 1982. Purification of acid beta-galactosidase and acid neuraminidase from bovine testis: Evidence for an enzyme complex. Biochem. Biophys. Res. Commun. 108: 868-875.

Verheijen, F.W., S. Palmeri, A.T. Hoogeveen, and H. Galjaard. 1985. Human placental neuraminidase: Activation, stabilization and association with beta-galactosidase and its protective protein. Eur. J. Biochem. 149: 315-321.

Walkley, S., M.A. Thrall, K. Dobrenis, M. Huang, P.A. March, D.A. Siegel, and S. Wurzelmann. 1994a. Bone marrow transplantation corrects the enzyme defect in neurons of the central nervous system in a lysosomal storage disease. Proc. Nat1. Acad. Sci. 91: 2970-2974.

Walkley, S., M. Thrall, K. Dobrenis, P. March, and S. Wurzelmann. 1994b. Bone marrow transplantation in neuronal storage disorders. Brain Pathol. 4: 376.

Wenger, D.A. and C. Williams. 1991. Screening for lysosomal disorders. In Techniques in diagnostic human biochemical genetics (ed. F.A. Hommes), pp. 587-617. Wiley-Liss, New York.

Wenger, D.A., T.J. Tarby, and C. Wharton. 1978. Macular cherry-red spots and myoclonus with dementia: Coexistent neuraminidase and $\beta$-galactosidase deficiencies. Biochem. Biophys. Res. Commun. 82: 589-595.

Yamamoto, Y. and K. Nishimura. 1987. Copurification and separation of beta-galactosidase and sialidase from porcine testis. Int. J. Biochem. 19: 435-442.

Yamanaka, S., M.D. Johnson, A. Grinberg, H. Westhphal, J.N. Crawley, M. Taniike, K. Suzuki, and R.L. Proia. 1994. Targeted disruption of the Hexa gene results in mice with biochemical and pathologic features of Tay-Sachs disease. Proc. Natl. Acad. Sci. 91: 9975-9979. 


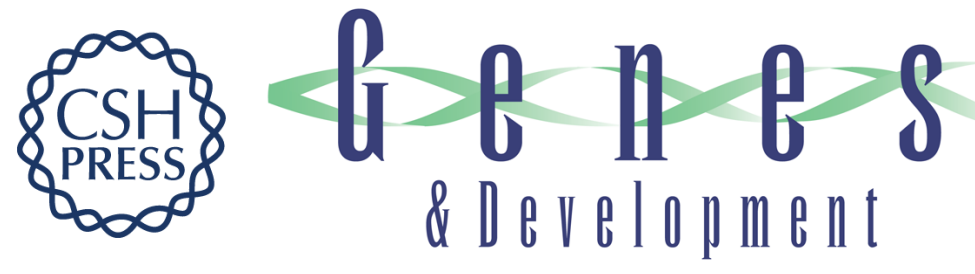

\section{Mouse model for the lysosomal disorder galactosialidosis and correction of the phenotype with overexpressing erythroid precursor cells.}

X Y Zhou, H Morreau, R Rottier, et al.

Genes Dev. 1995, 9:

Access the most recent version at doi:10.1101/gad.9.21.2623

References This article cites 49 articles, 15 of which can be accessed free at:

http://genesdev.cshlp.org/content/9/21/2623.full.html\#ref-list-1

License

Email Alerting

Service

Receive free email alerts when new articles cite this article - sign up in the box at the top right corner of the article or click here.

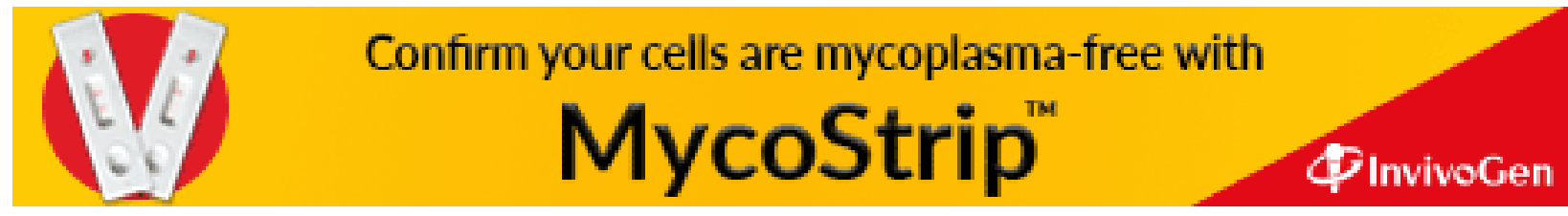

